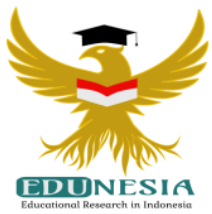

\title{
Studi Tingkat Pendidikan Terhadap Pengetahuan, Sikap, dan Pola Kebiasaan Masyarakat Pada Burung-Burung Yang Dikonsumsi di Kecamatan Danau Panggang
}

\author{
Masnurul Sholihah \\ Pendidikan Biologi, SMPN 4 Danau Panggang, Indonesia. \\ Corresponding Email: masnurlsholihah@gmail.com, Phone Number: 0822 xxxx xxxx
}

\author{
Article History: \\ Received: Nov 09, 2020 \\ Revised: Nov 11, 2020 \\ Accepted: Nov 12, 2020 \\ Published: Jan 01, 2021
}

Keywords:

Attitudes, Consumption and Birds, Education, Knowledge, Habit Patterns.

\section{Kata Kunci:}

Konsumsi dan Burung, Pendidikan, Pengetahuan, Pola Kebiasaan, Sikap.

\footnotetext{
How to cite:

Sholihah, M. (2021). Studi

Tingkat Pendidikan Terhadap Pengetahuan, Sikap, dan Pola Kebiasaan Masyarakat Pada Burung-Burung Yang Dikonsumsi di Kecamatan Danau Panggang. Edunesia: Jurnal Ilmiah Pendidikan, 2 (1) 104-112.
}

This is an open access article under the CC-BY-NC-ND license
Abstract: This study aims to describe attitudes and measure the level of knowledge of the people living around Lake Panggang to conserving birds that can be consumed. The variables of this research include variables of habits, attitudes, knowledge and level of public education in the form of elaborating research variables into sub variables and empirical indicators. The conclusion of this study is that knowledge and attitudes are not related to the level of community education in Pandamaan and Palukahan villages in the preservation of birds that can be consumed in Danau Panggang District. The people in Pandamaan and Palukahan villages have similarities in their habit patterns, namely they do not conserve birds that can be consumed. When viewed statistically, the habit patterns of the people of Pandamaan and Palukahan Villages are not significantly different in conserving birds that can be consumed.

Abstrak: Penelitian ini bertujuan untuk mendeskripsikan sikap dan mengukur tingkat pengetahuan masyarakat yang tinggal di sekitar Danau Panggang dalam melestarikan burung-burung yang dapat dikonsumsi. Variabel penelitian ini meliputi variable kebiasaan, sikap, pengetahuan dan tingkat pendidikan masyarakat dalam bentuk penjabaran variable penelitian menjadi sub variable dan indikator empiris. Keaimpulan dari penelitian ini adalah bahwa pengetahuan dan sikap tidak berhubungan dengan tingkat pendidikan masyarakat di Desa Pandamaan dan Desa Palukahan dalam pelestarian burung-burung yang dapat dikonsumsi di Kecamatan Danau Panggang. Masyarakat di Desa Pandamaan dan Desa Palukahan memiliki kesamaan dalam pola kebiasaan yaitu sama - sama tidak melestarikan burung - burung yang dapat dikonsumsi. Bila dilihat secara statistik pola kebiasan masyarakat Desa Pandamaan dan Desa Palukahan tidak berbeda secara signifikan dalam melestarikan burung burung yang dapat dikonsumsi. 


\section{A. Pendahuluan.}

Burung merupakan sumber plasma nuffah yang memberikan kekayaan bagi fauna di Indonesia. Burung memiliki peran yang penting dalam suatu ekosistem. Manfaat burung di alam diantaranya berperan dalam proses ekologi, yaitu sebagai penyeimbang rantai makanan dalam ekosistem, membantu proses penyerbukan tanaman khususnya tanaman yang mempunyai perbedaan antara posisi benang sari dan putik, serta sebagai predator terhadap hama tanaman seperti serangga dan tikus (Anonim, 2011). Selain itu ada sebagian burung yang dapat dikonsumsi oleh masyarakat.

Masyarakat sering menangkap burung untuk diperjualbelikan atau dikonsumsi.Keterlibatan masyarakat dalam penangkapan dan perjualbelikan burungburung, dikonsumsi terlihat jelas dan sangat mempengaruhi kelestarian burung.Ini diperparah dengan fakta bahwa sebagian besar masyarakat tidak mengetahui bahwa burung-burung yang mereka tangkap ada yang termasuk kedalam burung yang jumlahnya makin berkurang tiap tahunnya dan perlu untuk dilestarikan dialam.Sejak tahun 2007, burung Indonesia secara berkala memantau status keterancaman dari burungburung terancam punah yang berada di Indonesia berdasarkan data dari BirdLife International. Tahun 2007-2009 terjadi penurunan status keterancaman burung secara berturut-turut mulai dari 119 jenis (2007), 118 jenis (2008), dan 117 jenis (2009) (Anonim, 2011). Burung-burung yang dilestarikan jumlahnya ada sekitar 93 jenis yang diantaranya Cairina scutulata (Itik liar), Esacus magnirostris (Burung lutut tebal), Mycteria leucocephala (Bangau), Bubulcus ibis (Burung putih) dan lain - lain (Anonim, 2011). Pegunungan Meratus juga menyimpan potensi keanekaragaman hayati yang sangat menarik. Salah satu potensi keanekaragaman hayati yang menarik adalah Burung. Dalam sebuah survey (Meratus Expedition, 2005) yang dilaksanakan oleh tim yang terdiri dari perwakilan YCHI, BICONS serta masyarakat lokal (dari PIM, Malaris - Loksado), dengan tajuk Mountain Meratus Conservation Management (MMCM), dijumpai sedikitnya 316 jenis burung dari 47 suku. Namun 316 jenis ini masih belum menggambaran secara keseluruhan keanekaan jenis burung di kawasan Pegunungan Meratus, oleh karena cakupan wilayah survei yang tidak terlalu luas serta survei dilakukan pada satu musim saja dan belum pada musim migrasi burung.

Penyebab burung ditangkap dan diperjualbelikan seperti uraian diatas, diduga adalah tingkat pendidikan yang rendah. Hal ini dikatakan oleh Harjosumantri (2018), salah satu faktor yang menyebabkan menurunnya kualitas lingkungan hidup, yaitu rendahnya tingkat pendidikan dan pengetahuan masyarakat, sehingga masyarakat kurang respon untuk dapat menerima informasi yang bermanfaat bagi mereka. Dengan pendidikan dapat ditanamankan berpikir kritis, kreatif dan rasional. Untuk itu perlu adanya penyuluhan dan bimbingan kepada masyarakat tentang upaya pelestarian burung-burung yang dapat dikonsumsi tersebut.

\section{B. Metode.}

Populasi dalam penelitian ini adalah seluruh masyarakat yang merupakan kepala keluarga atau yang mengambil peran sebagai kepala keluarga yang tinggal di sekitar Danau Panggang, yaitu Desa Pandamaan dan Palukahan. Kedua desa ini dijadikan sampel dengan alasan jumlah penduduknya yang lebih banyak dan mereka mengkonsumsi burung sebagai lauk selain ikan, serta karakteristik wilayah pedesaaan yang merupakan 
daerah rawa danau. Sampel penelitian diambil sebanyak $10 \%$ dari jumlah kepala keluarga Desa Pandamaan 556 atau 56 kepala keluarga, Palukahan 352 atau 36 kepala keluarga. Dasar penetapan pengambilan sampel 10 - $15 \%$ dari populasi terjangkau (Arikunto,2010).

Teknik pengambilan sampel adalah dengan Sampling Purposive, karena dua pertimbangan. Pertama, sampel yang diambil adalah kepala keluarga atau orang yang mengambil peran sebagai kepala keluarga karena orang yang lebih tahu tentang seluk beluk keluarga, pencari nafkah utama dan pengambilan keputusan dalam keluarga. Kedua, sampel yang berkaitan dengan kegiatan baik secara langsung atau tidak langsung dengan keberadaan burung-burung yang dikonsumsi.

Instrumen yang digunakan berupa kuesioner. Kuesioner terdiri atas dua bagian yaitu identitas responden dan daftar pertanyaan berkaitan dengan perilaku, sikap. dan pengetahuan masyarakat.

Hasil pengumpulan data selajutnya akan dianalisis dengan menggunakan pendekatan statistik secara kualitatif dan kuantitatif. Secara kualitatif dilakukan dengan pendekatan statistik deskriptif, yaitu dengan Sampling Purposive, sedangkan secara kuantitatif dilakukan dengan pendekatan statistik inferensial, yaitu non parametrik dengan menggunakan Sign Test (uji tanda).

Statistik non parametrik dengan menggunakan Uji Tanda sebagai berikut:

$\mathrm{P}=\sum\left(\begin{array}{l}\mathrm{N} \\ \mathrm{x}\end{array}\right) \mathrm{p}^{\mathrm{x}} Q^{(N-x)}$

Harga $\left(\begin{array}{l}N \\ x\end{array}\right)$ dicari dari :

$\left(\begin{array}{l}\mathrm{N} \\ \mathrm{X}\end{array}\right)=\frac{N !}{x !(N-x) !}$

Keterangan : Arah Perbedaan

$\mathrm{XP}=\mathrm{XT}=0$

$\mathrm{XP}<\mathrm{XT}=-$

$\mathrm{XP}>\mathrm{XT}=+$

$\mathrm{N}=$ Banyaknya pasangan yang menunjukkan perbedaan

$\mathrm{x}$ = Banyaknya tanda $(+)$ atau (-) yang jumlahnya lebih kecil

$\mathrm{p}=$ proporsi kasus yang diharapkan dalam satu katagori

$\mathrm{q}=$ Proporsi katagori yang lainnya

(Siegel,2011).

Misalkan $\mathrm{N}$ menyatakan banyak pasangan yang menghasilkan tanda positif $\left(^{(+)}\right.$ dan negative (-) setelah dihilangkan pasangan $\mathrm{XP}=\mathrm{XT}$. Selanjutnya nilai $\mathrm{x}$ menyatakan banyak tanda $(+)$ dan $(-)$ yang paling sedikit. Nilai $x$ ini dapat dipakai untuk menguji hipotesis :

- Ho di tolak jika harga nilai $x$ lebih kecil atau sama dengan nilai $x$ yang didapat dari daftar untuk taraf nyata yang dipilih.

- Ho di terima jika nilai x lebih besar dari nilai yang didapat dari daftar untuk taraf nyata yang dipilih (Sudjana, 2019). 


\section{Hasil dan Pembahasan.}

Data pengetahuan masyarakat terhadap pemanfaatan burung, perburuannya dan usaha pelestariannya di Desa Pandamaan dan Desa Palukahan yang terdapat di Kecamatan Danau Panggang dapat dilihat pada tabel berikut :

Tabel 1.

Ringkasan Pengetahuan Masyarakat di Desa Pandamaan dan Desa Palukahan Menurut Tingkat Pendidikan.

\begin{tabular}{|c|c|c|c|c|c|c|c|c|c|c|c|c|c|c|c|c|c|c|c|c|c|}
\hline \multirow[t]{2}{*}{ Nama Desa } & \multirow{2}{*}{$\begin{array}{c}\text { Tingkat } \\
\text { Pendidikan }\end{array}$} & \multicolumn{20}{|c|}{ Instrumen Pengetahuan Menurut Tingkat Pendidikan } \\
\hline & & 1 & 2 & 3 & 4 & 5 & 6 & 7 & 8 & 9 & 10 & 11 & 12 & 13 & 14 & 15 & 16 & 17 & 18 & 19 & 20 \\
\hline \multirow{3}{*}{ Pandamaan } & $\bar{D}$ & 1 & 1 & 1 & 1 & 1 & 1 & 1 & 1 & -1 & 1 & 1 & 1 & -1 & -1 & 1 & 1 & 1 & 1 & 1 & 1 \\
\hline & $\mathbf{M}$ & 1 & 1 & 1 & 1 & 1 & 1 & 1 & 1 & 1 & 1 & 1 & 1 & -1 & -1 & 1 & 1 & 1 & 1 & 1 & 1 \\
\hline & $T$ & 1 & 1 & 1 & 1 & 1 & 1 & 1 & 1 & 0 & 1 & 1 & 1 & 0 & 0 & 1 & 1 & 1 & 1 & 1 & 1 \\
\hline \multirow{3}{*}{ Palukahan } & D & 1 & 1 & 1 & 1 & 1 & 1 & 1 & 1 & -1 & 1 & 1 & 1 & -1 & -1 & 1 & 1 & 1 & 1 & 1 & 1 \\
\hline & $\mathbf{M}$ & 1 & 1 & 1 & 1 & 1 & 1 & 1 & 1 & -1 & 1 & 1 & 1 & -1 & -1 & 1 & 1 & 1 & 1 & 1 & 1 \\
\hline & $T$ & 0 & 0 & 0 & 0 & 0 & 0 & 0 & 0 & 0 & 0 & 0 & 0 & 0 & 0 & 0 & 0 & 0 & 0 & 0 & 0 \\
\hline
\end{tabular}

Berdasarkan tabel 1 tentang pengetahuan masyarakat di Desa Pandamaan dan Desa Palukahan menurut tingkat pendidikan pada tingkat pendidikan dasar (D), Pendidikan menengah (M), dan Pendidikan tinggi (T) umumnya mengetahui pemanfaatan, penanggulangan, dan usaha pelestarian terhadap burung-burung yang dapat dikonsumsi di Kecamatan Danau Panggang hal ini ditunjukkan dari hasil persentasi yang menjawab ya (Y) lebih tinggi dibandingkan dengan yang menjawab tidak (T).

Tabel 2.

Ringkasan Sikap Masyarakat di Desa Pandamaan dan Desa Palukahan Menurut Tingkat Pendidikan.

\begin{tabular}{|c|c|c|c|c|c|c|c|c|c|c|c|c|c|c|c|c|c|c|c|c|c|}
\hline \multirow{2}{*}{$\begin{array}{c}\text { Nama } \\
\text { Desa }\end{array}$} & \multirow{2}{*}{$\begin{array}{c}\text { Tingkat } \\
\text { Pendidikan }\end{array}$} & \multicolumn{20}{|c|}{ Instrumen Sikap Menurut Tingkat Pendidikan } \\
\hline & & 1 & 2 & 3 & 4 & 5 & 6 & 7 & 8 & 9 & 10 & 11 & 12 & 13 & 14 & 15 & 16 & 17 & 18 & 19 & 20 \\
\hline \multirow[b]{3}{*}{ Pandamaan } & $\mathrm{D}$ & -1 & 1 & 1 & 1 & 1 & 1 & 1 & 1 & 1 & 1 & 1 & 1 & 1 & 1 & 1 & -1 & -1 & 1 & 1 & 1 \\
\hline & $\mathrm{M}$ & -1 & -1 & 1 & 1 & 1 & 1 & 1 & 1 & 1 & -1 & 1 & -1 & 0 & 1 & 1 & 1 & 1 & 1 & 1 & 1 \\
\hline & $\mathrm{T}$ & -1 & 0 & 0 & 1 & 1 & 1 & 1 & 1 & 0 & 0 & 1 & 0 & 1 & 1 & 1 & 0 & 1 & 1 & 1 & 1 \\
\hline \multirow{3}{*}{ Palukahan } & D & -1 & -1 & 1 & 1 & 1 & 1 & 1 & 1 & 1 & 1 & 1 & 1 & 1 & -1 & -1 & -1 & 1 & 1 & 1 & 1 \\
\hline & $\mathrm{M}$ & -1 & -1 & 1 & 1 & 0 & 1 & 1 & 1 & 1 & 1 & 1 & -1 & 1 & -1 & -1 & -1 & 1 & 1 & 1 & 1 \\
\hline & $\mathrm{T}$ & 0 & 0 & 0 & 1 & 1 & 0 & 0 & 0 & 0 & 0 & 0 & 0 & 1 & 0 & 0 & 0 & 0 & 0 & 0 & 0 \\
\hline
\end{tabular}


Berdasarkan tabel 2 tentang sikap masyarakat di Desa Pandamaan dan Desa Palukahan menurut tingkat pendidikan baik pada pendidikan dasar, pendidikan menengah dan pendidikan tinggi terhadap pernyataan sikap untuk melestarikan burungburung yang dapat dikonsumsi dan sikap yang tidak melestarikan burung ditunjukkan dari hasil presentasi yang menjawab ya $(\mathrm{Y})$ dengan yang menjawab tidak $(\mathrm{T})$ jauh berbeda.

Pola kebiasaan di sini adalah pola kebiasaan dalam memperlakukan kawasan Danau Panggang sebagai tempat perburuan burung yang dikonsumsi khususnya di dua desa yaitu Desa Pandamaan dan Desa Palukahan. Pola kebiasaan masyarakat terdiri atas yang melestarikan dan yang tidak melestarikan burung - burung yang dapat dikonsumsi tersebut. Data tentang pola kebiasaan masyarakat di Desa Pandamaan dan Desa Palukahan ini dapat dilihat pada tabel 3 berikut:

Tabel 3.

Ringkasan Pola Kebiasaan Masyarakat di Desa Pandamaan dan Desa Palukahan Menurut Tingkat Pendidikan.

\begin{tabular}{cccccccccccc}
\hline $\begin{array}{c}\text { Nama } \\
\text { Desa }\end{array}$ & $\begin{array}{c}\text { Tingkat } \\
\text { Pendidikan }\end{array}$ & \multicolumn{8}{c}{$\begin{array}{c}\text { Instrumen Pola Kebiasaan Menurut Tingkat } \\
\text { Pendidikan }\end{array}$} \\
\cline { 2 - 13 } & & 1 & 2 & 3 & 4 & 5 & 6 & 7 & 8 & 9 & 10 \\
\hline \multirow{3}{*}{ Pandamaan } & $\mathrm{D}$ & 1 & -1 & -1 & -1 & -1 & -1 & -1 & -1 & -1 & -1 \\
& $\mathrm{M}$ & 1 & -1 & -1 & -1 & 0 & -1 & 0 & 1 & -1 & 0 \\
\cline { 2 - 12 } & $\mathrm{T}$ & 1 & -1 & -1 & -1 & -1 & 1 & -1 & 0 & 0 & -1 \\
\hline \multirow{3}{*}{ Palukahan } & $\mathrm{D}$ & 1 & -1 & -1 & 1 & -1 & -1 & 1 & 1 & 1 & 1 \\
\cline { 2 - 12 } & $\mathrm{M}$ & 1 & -1 & -1 & -1 & 0 & -1 & -1 & 1 & 1 & 1 \\
\cline { 2 - 11 } & $\mathrm{T}$ & 0 & 0 & 0 & 0 & -1 & 1 & 0 & 0 & 0 & 0 \\
\hline
\end{tabular}

Berdasarkan tabel 3 tentang pola kebiasan masyarakat menurut tingkat pendidikan di dua desa yaitu Desa Pandamaan dan Desa Palukahan ternyata baik pada tingkat pendidikan dasar, pendidikan menengah dan pendidikan tinggi menunjukkan bahwa pola kebiasaan mereka cenderung kepada hal yang tidak mendukung kelestarian dari burung burung yang dapat dikonsumsi, hal ini ditunjukkan dari hasil presentasi yang menyatakan pola kebiasaan yang melestarikan lebih rendah daripada dengan yang tidak melestarikan.

Data tentang pola kebiasaan masyarakat di Desa Pandamaan dan Desa Palukahan dalam melestarikan dan yang tidak melestarikan burung - burung yang dikonsumsi di sajikan pada lampiran 6. Di Desa Pandamaan jumlah skor 1 (melestarikan) ada 4 , sedangkan skor 0 (tidak melestarikan) ada 26. Ini menunjukkan bahwa masyarakat Desa Pandamaan memiliki pola kebiasaan cenderung tidak melestarikan sedangkan di Desa Palukahan jumlah skor 1 ada 10 dan skor 0 ada 20. Ini berarti bahwa pola kebiasaan masyarakat Desa Palukahan juga cenderung tidak melestarikan burung - burung yang dapat dikonsumsi.

Berdasarkan hasil penelitian di Desa Pandamaan dan Desa Palukahan adalah memiliki pola kebiasaan yang sama yaitu tidak melestarikan kawasan Danau Panggang sebagai tempat dari burung - burung yang dapat dikonsumsi. Hal ini berdasarkan hasil 
perhitungan dengan menggunakan uji tanda terdapat nilai $p=0,188, p>0,05$ berarti kedua desa tersebut cenderung tidak melestarikan burung - burung yang dapat dikonsumsi, maka Ha diterima dan Ho ditolak

Masyarakat di Desa Pandamaan dan Desa Palukahan pada semua tingkat pendidikan sebagian besar mengetahui jenis - jenis burung. Pada data kuesioner yang diberikan kepada responden dapat kita simpulkan kedalam 5 (lima) bentuk kategori pertanyaan. Pada pendidikan dasar (D) sebagian besar mengetahui pengetahuan tentang burung yang dapat dikonsumsi begitu pula pada pendidikan menengah (M) dan pendidikan tinggi $(\mathrm{T})$.

Pengetahuan masyarakat tentang pemanfaatan burung pada tingkat pendidikan sebagaian besar diketahui oleh masyarakat pada pendidikan dasar dan sebagian kecil pada pendidikan menengah dan pendidikan tinggi. Pengetahuan masyarakat tentang penurunan populasi burung juga diketahui sebagian besar oleh masyarakat pendidikan dasar dan sebagaian kecil oleh pendidikan menengah dan pendidikan tinggi. Pengetahuan tentang pelarangan melakukan perburuan atau penangkapan burung yang dapat dikonsumsi pada tingkat pendidikan dasar sebagian besar mengetahui dan sebagaian kecil diketahui oleh pendidikan menengah dan tinggi. Pengetahuan masyarakat tentang pembudidayaan dan pelestarian burung diketahui sebagain besar oleh pendidikan dasar dan sebagaian kecil oleh pendidikan menengah dan tinggi. Demikian juga dengan pengetahuan tentang kawasan atau tempat hunian burung sebagian besar diketahui oleh masyarakat yang berpendidikan dasar dan sebagian kecil masyarakat yang pendidikan menengah dan tinggi.

Berdasarkan hal tersebut maka pengetahuan masyarakat pada ke dua desa yaitu Desa Pandamaan dan Desa Palukahan tidak dipengaruhi oleh tingkat pendidikan yang mereka peroleh karena ada masyarakat memiliki pengetahuan yang baik tetapi tingkat pendidikannya rendah sebaliknya ada masyarakat yang memilki pendidikan yang tinggi tetapi pengetahuannya rendah mengenai hal-hal pengetahuan tentang burung, pemanfaatan burung, penurunan populasi burung, pelarangan perburuan atau penangkapan burung, pembudidayaan dan pelestarian burung dan kawasan atau tempat yang menjadi hunian burung. Kondisi ini bertentangan dengan suatu pernyataan yang mengatakan bahwa melalui pendidikan masyarakat dibekali pengetahuan, sikap dan keterampilan yang diperlukan, sehingga mereka menjadi tahu, mengerti dapat melakukan dan mau melakukan sesuatu untuk peningkatan kualitas hidup. Semakin tinggi tingkat pendidikan seseorang semakin tingggi peran yang dapat dimainkan dalam kehidupan di masyarakat (Davis, 1993 dalam Rahmiati,Finna : 2011), selain itu berdasarkan kenyataan dilapangan bahwa tingkat pendidikan masyarakat di kedua desa tersebut memang sebagian besar hanya memiliki atau mengecap pendidikan dasar tetapi mereka memperoleh pendidikan tambahan dari media lain seperti radio dan televisi serta mereka menyekolahkan putra dan putri mereka kejenjang pendidikan yang lebih tinggi dari yang mereka peroleh.

Sikap masyarakat di Desa Pandamaan dan Desa Palukahan pada tingkat pendidikan sebagian kecil saja yang menyatakan melarang perburuan atau penangkapan burung yang dikonsumsi di Danau Panggang. Artinya masyarakat memiliki sikap negatif terhadap usaha pelestarian burung tersebut. Begitu juga pada pendidikan menengah dan pendidikan tinggi di kedua desa tersebut. Hasil penelitian juga menyimpulkan bahwa tingkat pendidikan yang rendah sangat mempengaruhi sikap dan prilaku masyarakat 
yang mengakibatkan semakin memburuknya keadaan penyakit Taeniasis solium. Tingkat pendidikan yang rendah akan mempengaruhi kesadaran dan prilaku seperti dilaporkan (Heryanto, 2012)

Pada dasarnya masyarakat tidak melarang orang melakukan perburuan atau penangkapan terhadap burung - burung yang dapat dikonsumsi di Danau Panggang, asalkan yang mereka ambil adalah burung yang sudah dewasa, menggunakan alat tradisional yang ramah lingkungan dan tidak merusak kawasan dari hunian burung tersebut. Jikalau ada mereka tertangkap burung yang belum dewasa biasanya mereka lepaskan dan ada juga yang dibawa pulang untuk dipelihara. Tetapi karena tingkat pendidikan yang rendah maka masyarakat tidak peduli dengan kelestarian dari burung burung yang dapat dikonsumsi, hal ini dapat dilihat dari hasil survey yang dilakukan bahwa masyarakat banyak yang menjawab ya $(Y)$ untuk pertanyaan soal nomor 7,8,11,14,15,16,18,19 dan 20 yang cenderung pada sikap yang tidak melestarikan dengan alasan bahwa burung - burung itu disediakan oleh alam dan harus dimanfaatkan dengan sebaik - baiknya dan bila kita kaitkan dengan factor ekonomi maka sikap atau prilaku yang mereka lakukan semata -mata karena untuk memanfaatkan semua hasil buruan dan tangkapan yang dapat menghasilkan uang untuk memenuhi kebutuhan hidup dan menambah penghasil. Perburuan atau penangkapan burung biasanya banyak mereka lakukan pada musim kemarau disaat masa sulit untuk mencari ikan. Mencari ikan (Nelayan) merupakan pekerjaan mereka sehari - hari sehingga pada saat itu perburuan atau penangkapan burung dilakukan untuk menambah penghasilan dimasa panceklik ikan.

Pola kebiasaan masyarakat terbentuk dari pengetahuan, sikap dan prilakunya. Masyarakat yang tinggal di sekitar kawasan hutan memiliki peran penting dalam rangka pelestarian hutan dan peranan dalam kerusakan hutan, artinya masyarakat memiliki pola kebiasaan untuk melestarikan hutan dan pola kebiasaan yang dapat merusak hutan yang dipengaruhi oleh persepsi dan prilaku masyarakat (Umar, 2011). Demikian juga pada masyarakat di Desa Pandamaan dan Desa Palukahan yang tinggal disekitar kawasan hunian burung sangat berperan dalam menjaga kelestarian dan ketidaklestarinya burung -burung yang dapat dikonsumsi tersebut. Akan tetapi berdasarkan hasil penelitian yang dapat dilihat pada tabel 4 ternyata masyarakat di kedua desa memiliki pola kebiasaan yang tidak melestarikan terhadap burung - burung yang dapat dikonsumsi.

Pola kebiasaan masyarakat yang cenderung tidak melestarikan tersebut bukan saja karena masyarakat di dua desa ini hanya mengecap pendidikan dasar, akan tetapi ada faktor lain yang mendukung tindakan mereka untuk tidak melestarikan burung dengan alasan ekonomis, yaitu menambah penghasilan sehingga masyarakat melakukan perburuan atau penangkapan burung tanpa ada upaya untuk melestarikan burung burung tersebut dan alasan lain bahwa burung - burung tersebut bebas di alam serta banyak jumlahnya di daerah Danau Panggang.

Tidak ada perbedaan pola kebiasaan antara masyarakat di Desa Pandamaan dan Desa Palukahan dimana kedua desa ini memiliki pola kebiasaan yang tidak melestarikan burung - burung yang dapat dikonsumsi, hal ini dilihat dari hasil perhitungan dengan uji tanda dimana menunjukkan bahwa pola kebiasaan masyarakat melestarikan sangat rendah dibandingkan dengan pola kebiasaan yang tidak melestarikan. Masyarakat di dua desa ini sebagian besar hanya mencapai tingkat pendidikan dasar. Temuan ini sejalan dengan penelitian sebelumnya (Amani, 2008; Sukana, 2012; Zahara, 2001; Heryanto 2012). 
Para peneliti ini pada dasarnya menemukan ada hubungan antara tingkat pendidikan yang masih rendah dengan kebiasaan maupun manisfestasi prilaku.

Dengan melihat keadaan ini maka diharapkan adanya kerja sama antara masyarakat dan pemerintah daerah dalam menanggulangi permasalahan kelestarian dari burung - burung yang dapat dikonsumsi dengan cara melakukan penyuluhan dan pelarangan mengenai perburuan atau penangkapan hewan ini secara besar - besaran sehingga terjaga kelestariannya selain itu pemahaman yang baik tentang pentingnya menjaga kelestarian alam dan isinya di kawasan Danau Panggang juga dapat ditanamkan melalui bidang pendidikan yaitu dengan memuat materi pelajaran tentang aneka burung dan pemanfaat serta kelestariannya pada bidang pelajaran IPA.

\section{Kesimpulan.}

Pengetahuan dan sikap tidak berhubungan dengan tingkat pendidikan masyarakat di Desa Pandamaan dan Desa Palukahan dalam pelestarian burung-burung yang dapat dikonsumsi di Kecamatan Danau Panggang. Masyarakat di Desa Pandamaan dan Desa Palukahan memiliki kesamaan dalam pola kebiasaan yaitu sama - sama tidak melestarikan burung - burung yang dapat dikonsumsi.

\section{Daftar Pustaka.}

Amani, M., \& Hadi, A. (2008). Kajian Tentang Sikap, Faktor Sosial, Faktor Ekonomi, Dan Pola Hubungannya dengan Kebiasaan Masyarakat yang Tinggal Di Sekitar Kawasan Suaka Margasatwa Pulau Kaget Kabupaten Batola Terhadap Menurunnya Populasi Bekantan (Nasalis larvatus). Laporan Penelitian Banjarmasin: FKIP Unit Program Belajar Jarak Jauh UT.

Anonim. (2011). http://blogmhariyanto.blogspot.com/2009/07/daftar-burung-aves dilindungi.html.Diakses 16 November 2011.

Anonim. (2011). http://www.birdlife.org/worldwide/national/indonesia/index.html. Diakses 16 November 2011

Arikunto, S. (2010). Prosedur Penelitian suatu pendekatan Praktek. Jakarta: PenerbitRineka Cipta

Heryanto. (2012). Kondisi Sumber Air Minum dan Jamban Keluarga yang Berpengaruh dengan Kejadian Diare, (On line), http/litbang. depkes. Go.id/ekologi/ daftar abstrak berdasarkan tahun htm. Diakses 11 Maret 2012

Harjosumantri, Koesnadi.2018. Hukum Tata Lingkungan. Edisi ke-8. Yogyakarta. Universitas Gajah Mada

Rahmiati, F. (2011). Pola Kebiasaan Masyarakat Di Sekitar Kawasan Suaka Margasatwa Pulau Kaget Dalam Pelestarian Suaka Margasatwa Pulau Kaget Sebagai Habitat Bekantan (Nasalis larvatus Wurmb). Program Studi Magister Pendidikan Biologi. Program Pascasarjana. Universitas Lambung Mangkurat. Banjarmasin. 
Siegel, S. (2011). Statistik Non Parametrik Untuk Ilmu - ilmu Sosial. Copyright (c) 2011 Telkom Open Library.

Sudjana, N. (2019). Metoda Statistika. Edisi Terbaru 2019. Tarsito. Bandung

Sugiyono. (2011). Statistika untuk Penelitian. Alfabeta. Bandung

Sukana, B. (2012). Kualitas Air Bersih Di Pemukiman Sekitar TPA Sampah Bantar Gebang Bekasi. (Online). http://www.Litbang.depkes.go.id/ekologi/abstrak 98-99. Htm. Diakses 12 April 2012.

Umar. (2011). Persepsi dan Perilaku Masyarakat Dalam Pelestarian Fungsi Hutan Sebagai Daerah Resapan Air. (http://eprints.undip.ac.id/17567/umar.pdf/. Diakses tanggal 07 Mei 2011.

Yip, S.P. (1999). Educating it Student Ethics by Using a Cognitive Dissonance.Theory Perspective, (http://www. Businesit bf.niit.edu/aice/events/AICC C99/papers 1/YIP.Diakses tanggal 09 Mei 2011. 